\title{
Retracted Article: Phenotypic and molecular characterization of Salmonella Enteritidis isolates
}

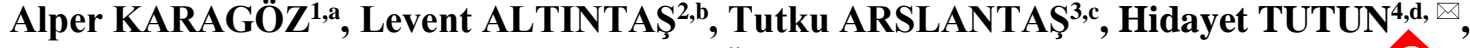 \\ Nadir KOÇAK ${ }^{5, e}$, Özlem ALTINTAŞ, \\ ${ }^{1}$ Uşak University, Department of Molecular Biology and Genetics, Uşak; ${ }^{2}$ Ankara University, Faculty of Veterinary Medichne, \\ Department of Pharmacology and Toxicology, Ankara; ${ }^{3}$ Çankırı Public Hospital, Microbiology Laboratory, Cankırı; ${ }^{4}$ Burdur \\ Mehmet Akif Ersoy University, Faculty of Veterinary Medicine, Department of Pharmacology and roxicology, Burdur; ${ }^{5}$ Selçuk \\ University, Medical Genetics, Konya; ${ }^{6}$ Veterinary Control Central Research Institute, Ankara, Turkey. \\ ${ }^{\mathrm{a}}$ ORCID: 0000-0002-8178-223X; ${ }^{\mathrm{b}}$ ORCID: 0000-0002-5148-723X; c ORCID: 0ø00-0002-4351-6500; \\ ${ }^{\mathrm{d}}$ ORCID: 0000-0001-9512-8637; ${ }^{\mathrm{e}}$ ORCID: 0000-0002-1727-1582; ${ }^{\mathrm{f}}$ ORCID:0000-0001-6467-9647 \\ Corresponding author: hidayettutun@ gmail_com \\ Received date: 20.02.2020 - Accepted date 01.07 .2020
}

\begin{abstract}
Salmonella spp. is the most frequently isolated foodborne pathogens causing human and animal diseases. The aim of this study was to investigate antimicrobial susceptibility profiles and the moleculartyping of 200 Salmonella Enteritidis strains isolated from the patients' stools between 2016 and 2019 in Turkey. The isolates were examined for antibiotic susceptibility patterns (21 antimicrobial agents) by Kirby-Bauer disc diffusion method or molecular typing by Pulsed-field gel electrophoresis (PFGE) and plasmid profiling. Although all isolates were susceptible to four antibiotics (suphamethoxazole/trimethoprim, chloramphenicol, streptomycin and trimethoprim), all were resistant to 15 different antibiotics. In the PFGE study performed with XbaI enzyme, all isolates were found to be related to each other according to sinilarity tates of $85 \%$ and above. There were two major clones, clone $\mathrm{A}$ and B. Clone A was divided into 6 pulsotypes (A1 A2-A3-A4-A5- 6 ) and clone B was divided into 3 pulsotypes (B1-B2-B3). Clone A had $87 \%$ similarity and Clone B had $90 \%$ similarity. The clystering rate was $86 \%(172 / 200)$. All isolates harboured $1-4$ plasmid ranging in size from 2.5 to $57 \mathrm{~kb}$ and showed 6 plasmid profiles (P1-P6). All isolates carried the $57 \mathrm{~kb}$ plasmid individually or in combination with other plasmids. Most of the isolates $136(68 \%)$ had P2 profile. Our findings indicate that the majority of all isolates were clonally related and had cross contamination problems. In this study, the importance of molecular typing methods in order to take more effective protection and controlmeasures against Salmonella has been demonstrated and proposed to use such methods.
\end{abstract}

Keywords: Antimicrobial resistance, PFGE, plasmid profiling, Salmonella Enteritidis.

\section{Salmonella Enteritrdis izolatlarının fenotipik ve moleküler karakterizasyonu}

Özet: Salınonella spp. insar ve hayvan hastalıklarına neden olan en yaygın gıda kaynaklı patojendir. Bu çalışmanın amacı, Türkiye'de 2016 ve 2019 yılları arasında hasta dışkılarından izole edilen 200 Salmonella Enteritidis izolatının antimikrobiyal duyarlılık profillerini ve moleküler tiplerini araştırmaktır. İzolatlar Kirby-Bauer disk difüzyon yöntemi ile antibiyotik duyarlılık profilleri (21 antibiyotik) ve pulsed-fheld jel elektroforezi (PFGE) ve plazmid profili ile moleküler tipleme açısından incelendi. Toplam 200 izolat hem 4 farklı antimikrobiyal ajana (sülfametoksazol / trimetoprim, kloramfenikol, streptomisin ve trimetoprim) duyarlı hem de 15 farklı antimikrobiyat ajəna dirençliydi. XbaI enzimi ile yapılan PFGE çalışmasında, tüm izolatların \%85 ve üzeri benzerlik oranlarına göre birbirlerıyle ilişsili olduğu bulundu. İki ana klon vardı, klon A ve B. Klon A, 6 pulsotipe (A1-A2-A3-A4-A5-A6) ve klon B, 3 pulsotipe (B1-B2-B3) ayr1ld1. Klon A ve B, sırasıyla \%87 ve \%90 benzerliğe sahipti. Kümeleme oran1 \%86 (172/200) idi. Tüm izolatlar, 2,5 ila $57 \mathrm{~kb}$ arasında değişen 1-4 plazmid barındırdı ve 6 plazmid profili (P1-P6) gösterdi. Tüm izolatlar 57 kb plazmidi tek veya diğer plazmidlerle birlikte taşıdı. İzolatların çoğu $(n=136, \% 68)$ P2 profiline sahipti. Bulgularımız, 200 S. Enteritidis izolatlarının çoğunun klonal olarak ilişkili olduğunu ve çapraz kontaminasyon problemleri olduğunu göstermektedir. Bu çalışmada, Salmonellosis'e karşı daha etkin korunma ve kontrol önlemlerinin alınmasında moleküler tipleme yöntemlerinin önemi gösterilmiş ve bu yöntemlerin kullanılması önerilmiştir.

Anahtar sözcükler: Antimikrobiyal direnç, PFGE, plazmid profili, Salmonella Enteritidis. 


\section{Introduction}

Salmonella is Gram-negative facultative anaerobic bacteria which belongs to-Enterobacteriaceae family and a group of bacteria living in the intestinal tracts of many different domestic animals including birds, cattle $(1,11$, 13). Humans usually become infected with Salmonella by eating foods contaminated with animals' feces $(1,11,39)$. Salmonellosis is an infectious disease of humans and animals caused by these bacteria which are capable of having foodborne zoonosis importance (18). Salmonella spp. especially $S$. enterica subsp. enterica serovar Enteritidis ( $S$. Enteritidis) and S. enterica subsp. enterica serovar Typhimurium ( $S$. Typhimurium) that are known as non-typhoidal Salmonella serotypes, continues to be the most frequent cause of bacterial foodborne disease outbreaks $(17-19,44)$. In addition, products of animal origin, environmental contamination and indirect transmission through food and water are other causes of Salmonella outbreaks $(4,38)$. Salmonella infection develops in adults with contaminated foods, and newborns and children are more likely to develop infections with cross-contamination (34).

Foodborne diarrheal diseases caused by the significant ones like non-typhoidal Salmonella are an important cause of morbidity and mortality, and thus has emerged as a significant and growing public health economic problem worldwide, especially industrialized countries $(14,27)$. Salmonella infections have a worldwide distribution and range clinicaly trom the common self-limited uncomplicated gastroenteritis to enteric fever (9).

Antibiotics inhibit the growth of Salmonella spp., reducing the economic losses and public health problems $(14,18)$. However, multidrug-re sistant Salmonella is increasing due to misuse and overuse of antibiotics in human and animals, which make it difficult to eliminate from its reseryour hosts (44). Multidrug-resistant Salmonella isolates have been associated with a considerable number of gytbreaks worldwide $(20,44)$. The presence antibiotic-resistant Salmonella in the human food chain pequires the development of newantibioticto-prevent the pathogens in reservoirs, including cattle, bitds (25). The identification of Salmonella serotypes is important to monitor common source outbreak or origins, relationships among different isolates and to control future outbreaks of infectious diseases that transmit from animals to humans $(4,9,11-13)$. The information to be obtained from typing methods such as Pulsed field gel electrophoresis (PFGE) and plasmid profile analysis (PPA) is very useful in preventing and controlling the spread of disease in animals and public (36). PPA is a molecular method used for subtyping (41). PFGE is also another molecular typing method used for typing outbreaks. This method provides information on the source and transmission pattern of the microorganism $(19,30)$. PFGE, which is used to determine the clonal and phylogenetical relationships between strains, is known to have high discrimination power $(2,4)$. Combined with PPA and PFGE provides a powerful discriminatory tool for the epidemiological analysis of $S$. Enteritidis isolates $(29,43)$. Most cases of Salmonellosis in humans are associated with the consumption of food contaminated with antibiotic-resistant $S$. Enteritidis from animals. Hence, it is possible to have a relationship between humans and animals regarding genotyping of antibioticresistant $S$. Enteritidis. This study amed to invgstigate the antimicrobial susceptibility profiles and the molecular typing of $200 \mathrm{~S}$. Enteritidis strains isolated from the patients admitted to the hospital by using PFGE and PPA and clarify the possible transmission rates and clonal relationships among these isolates

\section{Materials and Methods}

Samples: S. Enteritidis isolates $(\mathrm{n}=200)$ were used in this study. Fecal samples of 200 patients who were sent to a public hrospifal microbiology laboratory (Cankiri province of Turkey) between 2016 and 2019 were exannined. The study was performed by using $S$. Enteritidis obtained from the culture collection made from the fecal samples given by the patients who came to the butpatient clinic.

Salmonella Isolation and Identification: The samples were inoculated onto Eosin Methylene Blue (EMB) agar and Salmonella Shigella (SS) agar (Becton Dickinson, GmbH, Heidelberg, Germany) and into selenite F broth for enrichment (BBL Selenite F Broth, Becton Dickinson and Co., Sparks, MD, USA). They were incubated solid agars for overnight and selenite $\mathrm{F}$ broth for 8 hours under appropriate conditions. A single colony picked up and identified as $S$. Enteritidis using IMVIC test (citrate, methyl red, Voges-Proskauer, citrate, ornithine, urea, indole, Kligler iron agar media). Conventional methods (Triple Sugar Iron Agar, Simon's Citrate Agar, Urea Agar and nutrient broth.; Oxoid, Hampshire, UK) and Phoenix 100 (Becton Dickinson and Co., Sparks, MD, USA) automated system were used to identify lactose negative bacterial colonies that grow on EMB and SS agars and in selenite $\mathrm{F}$ medium. Serotypes of bacteria identified as Salmonella were determined by $\mathrm{O}$ and $\mathrm{H}$ antigens (Difco, Sparks, MD, USA). Somatic O antigens and flagellar $\mathrm{H}$ antigens were determined by slide agglutination using specific antisera. After the identification of the antigens, the name of strains was determined by using the Kauffman-White scheme (23, 24). Serological confirmation and serogroup of microorganisms identified as $S$. Enteritidis were 
determined by using species-specific anti-sera (Difco Shigella Antisera Poly, Sparks, MD, USA).

Antimicrobial susceptibility test: Mueller-Hinton agar (Oxoid, Hampshire, UK) was used for antibiotic susceptibility testing. Kirby-Bauer disc diffusion method was used for antibiotic susceptibility according to the Clinical Laboratory Standards Institute guidelines (6) for the following antimicrobial agents (Oxoid, UK): Ampicillin (AMP: $10 \mu \mathrm{g}$ ), cephalothin (KF: $30 \mu \mathrm{g}$ ), gentamicin (CN: $10 \mu \mathrm{g}$ ), amoxycillin-clavulanic acid (AMC: $30 \mu \mathrm{g}$ ), cefuroxime sodium (CXM: $30 \mu \mathrm{g}$ ), cefoperazone (CFP: $30 \mu \mathrm{g}$ ), cefotaxime (CTX: $30 \mu \mathrm{g}$ ), ceftizoxime (ZOX: $30 \mu \mathrm{g}$ ), ceftriaxone (CRO: $30 \mu \mathrm{g}$ ), ceftazidime (CAZ: $30 \mu \mathrm{g})$, suphamethoxazole/ trimethoprim (SXT: $25 \mu \mathrm{g}$ ), chloramphenicol (C: $30 \mu \mathrm{g}$ ), tetracycline (TE: $10 \mu \mathrm{g})$, kanamycin $(\mathrm{K}: 30 \mu \mathrm{g})$, nalidixic acid (NA: $30 \mu \mathrm{g}$ ), ciprofloxacin (CIP: $5 \mu \mathrm{g}$ ), sulphonamides (S3: $300 \mu \mathrm{g})$, streptomycin (S10: $10 \mu \mathrm{g})$, trimethoprim (W: $5 \mu \mathrm{g}$ ), cefpodoxime (CPD: $10 \mu \mathrm{g}$ ), and amikacin (AK: $30 \mu \mathrm{g})$. Escherichia coli ATCC 25922 was used as a quality control strain in all tests. The plates were incubated for 24 hours at $35-37^{\circ} \mathrm{C}$. The diameters of the inhibition zones formed around the discs were measured in millimeters and evaluated as susceptible, intermediate, or resistant, according to the CLSI, 2012 (6).

Plasmid analysis: Plasmid DNA was isolated by alkaline lysis methods of Kado and Liu (15) and separated in $0.7 \%$ agarose gel (Serva, Heidelberg Germany) prepared with $0.5 \times$ Tris-Boric acid-EDTA buffer at $10 \mathrm{~V}$ for $3 \mathrm{~h}$ at room temperature and stained with ethidium bromide $(0.5 \mu \mathrm{g})$. Plasmid size was determihed by comparison with $E$. coli V517 (53,7, 7.2, 5.6, 5, 1,3.9, 3.0, 2.7, $2.1 \mathrm{~kb}$ ) and $S$. Enteritidis strains (57.5.8, $4.8 \mathrm{~kb}$ ) and supercoiled DNA ladder $(1 \mathrm{~kb}$ gene ruler DNA ladder fermantas, Litvanya)

Pulsed field gelelectrophoresis: PFGE analysis was performed using $x$ ba according to the protocol described by Durmaz etal. (8). Briefly, single colony cultivation was performed on trypticase soy agar (Merck, Germany) from the bacteria that were jentified as $S$. Enteritidis incubated at $37{ }^{\circ} \mathrm{C}$ for 20-24 hours under aerobic conditions. After overnight incubation, the purity was checked, and a single colony of each isolate was again passaged to SS agar (Merck, Germany) and incubated under the same condition.

The colonies were collected with a plastic loop and suspended in $4 \mathrm{ml}$ of Cell Suspension Buffer (CSB; 100 $\mathrm{mM}$ Tris-HCL, $100 \mathrm{~mm}$ EDTA, pH 8.0). The cell suspension was centrifuged at $13000 \mathrm{rpm}$ for 2 minutes at $4^{\circ} \mathrm{C}$. The supernatant was discarded after centrifugation. 1 $\mathrm{ml}$ cold CSB was added to the pellet again and vortexed for a short time. The bacterial density was adjusted to 1 absorbance at $590 \mathrm{~nm}$ using a spectrophotometer (UV/Vis. Spectrophotometer, Shimadzu-1280, Japan). 2\% lowmelting agarose (LMA, Gibco BRL, Paisley, UK) was prepared in CSB buffer and the mixture containing CSB, LMA and $10 \%$ Sodium Dodecyl Sulfate (SDS, Merck, Germany) was transferred to plug molds (10mm x $5 \mathrm{~mm}$ x $1.5 \mathrm{~mm}$, Sigma-Aldrich, Germany). The molds were allowed to stand for 10 minutes at $+4{ }^{\circ} \mathrm{C}$ until the agarose solidifies for quality DNA preparation. The agaroses containing the bacteria were removed from the plug mold and transferred into Cell Lysis Solution 1 (CLS-1, 50 inM Tris- $\mathrm{HCl}$ (pH 8.0), 50 mM EDTA, $2.5 \mathrm{mg} / \mathrm{ml}$ lysozyme, $1.5 \mathrm{mg} / \mathrm{ml}$ proteinase $\mathrm{K}$ ) and inetbated for 1 hour at 37 ${ }^{\circ} \mathrm{C}$. Then, the plugs were incubated in Cell Lysis Solution2 (CLS-2, 0.5 M EDTA 1\% sarko\$yl, $400 \mu \mathrm{g} / \mathrm{ml}$ proteinase $\mathrm{K}$ ) at $55^{\circ} \mathrm{C}$ for 2 hours. After incubation, the plugs were treated 3 times successively with sterile ultrapure water (Reagent Grade Type 1) and TE buffer (10 mM Tris-HCL, 0.1 mm EDTA, pH 7.6).

Each of the agarose containing DNA was transferred

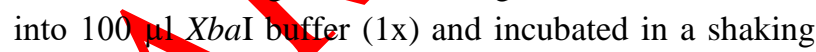
water bath at $37^{\circ} \mathrm{C}$ for 10 minutes. The restriction buffer was removed and fresh buffer $(100 \mu \mathrm{l})$ containing XbaI restriction enzyme (Promega Corporation, WI, USA) was added to each plug in the tubes. Incubation was performed at $37 \mathrm{C}$ for 2 hours. $1 \%$ agarose (pulsed-field certified agarose, Sigma-Aldrich, Germany) was prepared in 100 $\mathrm{ml}$ of $0.5 \times \mathrm{xBE}$ (44.5 mM Trisma Base, $44.5 \mathrm{mM}$ Boric acid, $1 \mathrm{mM}$ EDTA, pH 8.0) solution and restricted DNA plugs were loaded on each tooth of tooth comb (USA Scientific, USA). The agarose solidified on the teeth was placed in a PFGE chamber containing 1900-2000 ml 0.5x TBE buffer. PFGE was performed via CHEF-DR ${ }^{\circledR}$ II system (Bio-Rad, Hercules, CA, USA). The electrophoresis condition was set as follows: Initial switch time; $2.3 \mathrm{~s}$; final switch time, $65 \mathrm{~s}$, run time, $19 \mathrm{~h}$; gradient, $6 \mathrm{~V} / \mathrm{cm}^{2}$; angle $120^{\circ}$; temperature, $14{ }^{\circ} \mathrm{C}$. After electrophoresis, the gel was transferred into ultra-pure water containing ethidium bromide $(5 \mu \mathrm{g} / \mathrm{ml})$ and incubated to be stained for 20 minutes and visualized under UV light.

The DNA band images were photographed using Digi Genius Imaging System (Syngene, UK). Band profiles were analyzed using Gene Directory software (Syngene, Cambridge, UK). First of all, normalization was performed with the help of three control strains in each image. Clustering analysis was performed by creating a dendrogram of PFGE profiles. The relationship between the strains was determined according to the "Dice" similarity coefficient. Using the criteria developed by Tenover et al. (40), isolates were evaluated as indistinguishable, closely related, possibly related, or different. 


\section{Results}

The $S$. Enteritidis isolates were isolated from clinical specimens (200 fecal samples) in this study. There were the multi-resistant $S$. Enteritidis (100\%) which are resistant to a large diversity of antimicrobial agents (Figure 1). A total of 200 isolates were susceptible to four antimicrobial agents (SXT, C, S10 and W). The antibiotic resistance profiles were similar among $S$. Enteritidis isolates which are resistant to more antibiotics. The susceptibility and resistance patterns of the strains were found to be similar and were mainly divided into 3 groups as RI, RII and RIII (Table 1).

Molecular typing of the $S$. Enteritidis isolates were analyzed by using molecular techniques, PFGE and PPA. In the PFGE study performed for genotypic typing of $S$. Enteritidis, PFGE gel images were obtained after cutting Salmonella DNA with XbaI enzyme with restriction endonuclease activity. In the next step, dendrogram analysis was performed from gel images of Salmonella isolates showing PFGE band profiles. After the band profile analysis, PFGE profile dendrograms were established and the relationships between strains were determined. Cluster analysis was evaluated with the Dice similarity coefficient and UPGMA (Unweighted Pair Group Method Average) relationship rule parameters. When the dendrogram of 200 Salmonella strains were examined; according to the criteria of Tenover et al. (40), $S$. Enteritidis were found to be related to each other according to similarity rates of $85 \%$ and above. There were two major clones, but strains were divided into clones $\mathrm{A}$ and $\mathrm{B}$. Clone $\mathrm{A}$ was divided into 6 pulsotypes (A1-A2-A3-A4-A5-A6) and clone B was divided into 3 pulsotypes (B1-B2-B3). Clone A had $87 \%$ similarity and Clone B had $90 \%$ similarity. The clustering rate was $86 \%$ (172/200) according to Tenover criteria (40). Clone A contained 172 strains and clone B contained 28 strains (Figure 1).

In this study, all of the $S$. Enteritidis isølates $(n=200)$ were observed to have plasmid. It was determined that isolates showed 6 plasmid profiles (P1-P6) (Table 2). The 200 isolates carrying plasmids yere found to carry 1-4 plasmids, ranging in size from 2.5 to $57 \mathrm{~kb}$ (Table 2). All isolates carried the $57 \mathrm{~kb}$ plasmid individually or in combination with other plasmids. Fourteen of the isolates carried at least one plasmid $(57 \mathrm{~kb})$. Most of the isolates $(\mathrm{n}=136,68 \%)$ had $\mathrm{P} 2$ profile.

\begin{tabular}{|c|c|c|c|}
\hline $\begin{array}{l}\text { Resistance } \\
\text { phenotype }\end{array}$ & . & Isolate number & $\%$ \\
\hline RI & $\begin{array}{l}\text { AMP, KF, CN, AMC, CXM, CFP, CTX, ZOX, CRO, CAZ, TE, K, } \\
\text { NA, CIP, S3, CPO, AK }\end{array}$ & 28 & 14 \\
\hline RII & $\begin{array}{l}\text { AMP, KF, CN, AMC, CXM, CTX ZOX, CRO, CAZ, TE, K, NA, } \\
\text { CIP, S3, CPO, AK }\end{array}$ & 121 & 60.5 \\
\hline RIII & AMC, CXM, ZOX, CRO, CAZ, TE, K, NA, CIP, S3, & 51 & 25.5 \\
\hline
\end{tabular}

Table 2. Plasmid parterns of $S$. Enteritidis isolates.

\begin{tabular}{lcc}
\hline Plasmid profiles & Plasmids $(\mathbf{k b})$ & Number of $\boldsymbol{S}$. Enteritidis isolates $(\%)$ \\
\hline P1 & 57 & $14(7)$ \\
P2 & $57,40,3.0$ & $136(68)$ \\
P3 & $57,40,6.5,4.5$ & $29(14.5)$ \\
P4 & $57,5.8,4.8$ & $7(3.5)$ \\
P5 & $57,6.5,4.5$ & $7(3.5)$ \\
P6 & $57,2.5$ & $7(3.5)$ \\
\hline
\end{tabular}




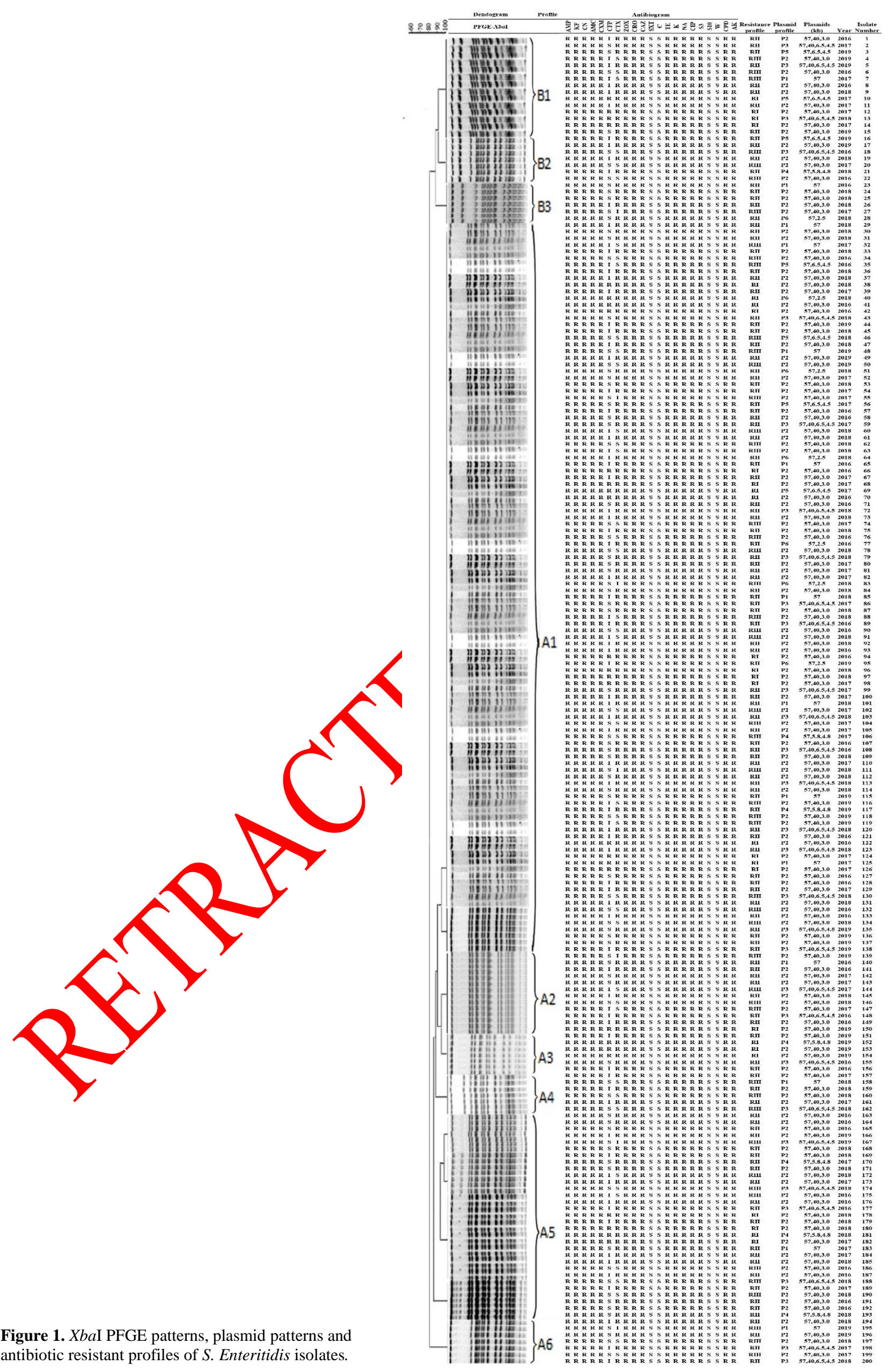




\section{Discussion and Conclusion}

Salmonella infection in humans and animals continues to be a public health problem in Turkey, as it is in almost every region of the world $(4,17,22)$. Phage typing and genotyping methods are accepted as the gold standard value for differentiation and subtyping of Salmonella isolates an epidemiological method $(28,35$, 45). Genotyping methods such as PFGE, PPA, ribotyping, which rely on the comparison of multiple electrophoresis banding patterns, have been used for monitoring the epidemic evolution of $S$. Enteritidis strains (1, 37). Salmonella phage typing is a method that can be performed in several reference centers in the world and is not implemented in Turkey. Therefore, our limited knowledge about phage types and molecular characteristics of isolated Salmonella serotypes in Turkey is based on a few specific studies and there is insufficient information about phage types and molecular characteristics of multi-drug resistant (MDR) $S$. Enteritidis strains (1, 21, 43).

$S$. Enteritidis is the most common Salmonella serotype isolated from the human in Turkey (10). From the past to the present, the incidence of $S$. Enteritidis has been gradually increasing in humans (3). The occurrence of antibiotic-resistant strains of Salmonella spp. has become a serious health problem worldwide $(5,7)$. High rates of resistance against a large number of antibiotics in $S$. Enteritidis isolates from humans and animals in Turkey have been reported previously $(3,10,12,13,21,26,33$ 42). In this study, there were the multitresistant $S$. Enteritidis (100\%) and all isolates were usceptible to four antimicrobial agents (SXT, C, S10 and W). The aptibiotic resistance profiles were similar among $S$. Enteritidis isolates which are resistant to more antibiotics. Erdem et al. (10) reported that there was resistance or decreased susceptibility to CIP in Salmonella enterica strains $(n=620)$ isolated fromclincal samples in 10 provinces of Turkey between 2000 and 2002 years. After about 17 years, all of the isolates were resistant to CIP in this study. These results shoy that increasing incidence of multi-drug resistant Salmohella strains represent a risk to public health.

In this study, molecular typing of the $S$. Enteritidis isolates was analyzed by molecular techniques, PFGE and PPA. All strains were found to be related to each other according to similarity rates of $85 \%$ and above. There were two major clones, divided into clones A and B. Clone A had $87 \%$ similarity and Clone B had $90 \%$ similarity. The clustering rate was $86 \%(172 / 200)$. In a study, PGFE profiles of $S$. Enteritidis strains $(\mathrm{n}=23)$ isolated from clinical samples from 7 provinces of Turkey between 2004 and 2010 have been determined using $X b a$ I restriction enzyme. The findings demonstrated that 4 different PFGE profiles (type 1, 4, 9, and 10) were found among serotype
S. Enteritidis and PFGE types had similarities below $85 \%$ and above $95 \%$ in strains within the same type (26). Us et al. (43) reported that a total of $122 \mathrm{~S}$. Enteritidis strains (epidemic, $\mathrm{n}=13$; sporadic, $\mathrm{n}=109$ ) (103 stool, 16 blood and one bile, one urine and one cerebrospinal fluid) isolated from 10 different provinces of Turkey after 2000 year were investigated for PFGE profile. The PFGE analysis showed 11 different patterns (a to k) and PFGE pattern $\mathrm{a}$ and $\mathrm{b}$ consisted of 53 strains $(43.4 \%)$ and 42 strains (34.4\%), respectively, after digestion with macrorestriction enzyme XbaI. In mid-anuary 2008 (Isparta province of Turkey), after a large foodborne outbreak associated with eggs eontaminated by $S$. Enteritidis in a military unit, $S$. Enteritidis was isolated from 276 stool samples and a blood sanple of the hospitalized patients and a food item. Authors have reported that the PFGE patterns after $X b a$ I digestion of these isolates were identical (19) Numerous studies in different countries reported that $S$. Enteritidis isolates were geneticafly similar and clonally highly related (16, 29-32). These datrare consistent with our results of PFGE profile after digestion of with $X b a I$ enzyme.

The plasmids carrying antibiotic resistance genes have an important role in transferring those genes to other strains or other species (25). In this study, all of the $S$. Enteritidis isolates $(n=200)$ were observed to have plasmid. The isolates carrying plasmids were found to carry 1-4 plasmids, ranging in size from 2.5 to $57 \mathrm{~kb}$. In a study conducted by Aktaş et al. (1) in Istanbul between 2001 and 2004, plasmid profiling analysis of pediatrics $S$. Enteritidis isolates showed six plasmid profiles, ranging in size from 2.5 MDa to $38 \mathrm{MDa}$. High rate (92\%) of the isolates harboured the same plasmid of $38 \mathrm{MDa}$. In another study in Ankara, although $S$. Enteritidis isolates harbored 1-4 plasmids with sizes ranging from 2.0 to 100 $\mathrm{kb}, 85(69.7 \%)$ of isolates harbored the $57 \mathrm{~kb}$ plasmid (43). In these studies, the plasmid size harboured by $S$. Enteritidis isolates are similar to those found in our study.

In the present study, the occurrence of multiresistance observed in $200(100 \%)$ of the $S$. Enteritidis isolates from clinical human samples is of great publish health concern and suggests the successful implementation of surveillance and monitoring of antimicrobial use and continuing education on prudent antimicrobial agent use. The high level of resistance observed in the isolates was likely to the fact antibiotics were overused to the patients. While no correlation was found between resistance profiles and genotypic profiles, it was determined that isolates showing multiple resistance to antibiotics were distributed to different PFGE clusters and different plasmid profiles.

In addition, our results revealed that the majority of $S$. Enteritidis isolates in Cankiri province of Turkey is similar PFGE pattern and confirmed the clonal structure 
of $S$. Enteritidis strains. Identification and typing of microorganisms at molecular level are very important. Investigating whether epidemiologically related isolates are genetically related may help to find the source and control spread of the epidemic in the community and hospitals (27).

In conclusion; combination of PFGE conducted with the restriction endonuclease $X b a \mathrm{I}$ and plasmid analysis was useful in detection of clonal relationship among $S$. Enteritidis. The importance of molecular typing methods in order to take more effective protection and control measures has been demonstrated and proposed to use such methods in this study.

\section{Financial Support}

This research received no grant from any funding agency/sector.

\section{Ethical Statement}

The study was approved by the ethic committee of Burdur Mehmet Akif Ersoy University (Ethic approval Code: GO 2020-258).

\section{Conflict of Interest}

The authors declared that there is no conflict of interest.

\section{References}

1. Aktas Z, Day M, Kayacan CB, et al (2007): Molecular characterization of Salmonella Typhtmurium and Salmonella Enteritidis by plasmid analy sis and pulsed-field gel electrophoresis. Int J Antimicrob Agents, 30, 541-545.

2. Alali WQ, Hofacre CL, Mathis-GF, et al (2013). Effect of essential oil compound on sheding and colonization of Salmonella enterica serovar Heidelberg in broilers. Poult Sci, 92, 836-841.

3. Aysev AD, Güriz H, Erden B (200\%): Drug resistance of Salmonella strain isolated from community infections in Ankara, Turkex 1993-99. Scané J Infect Dis, 33, 420-422.

4. Bhowmick PB, Srikumar S, Devegowda D, et al (2012): Serotyping and molecular characterization for study of genetic diversity among seafood associated non typhoidal Salmonella serquals. Indian J Med Res, 135, 371-381.

5. Brichta-Harhay DM, Arthur TM, Bosilevac JM, et al (2011). Diversity of multidrug-resistant Salmonella enterica strains associated with cattle at harvest in the United States. Appl Environ Microbiol, 77, 1783-1796.

6. CLSI (2012): M100-S25: Performance Standards for Antimicrobial Susceptibility Testing. Twenty-Fifth Informational Supplement.

7. De Oliveira FA, Pasqualotto AP, Da Silva WP, et al (2012): Characterization of Salmonella Enteritidis isolated from human samples. Food Research International, 45, 1000-1003.

8. Durmaz R, Otlu B, Koksal F, et al (2009): The optimization of a rapid pulsed-field gel electrophoresis protocol for the typing of Acinetobacter baumannii,
Escherichia coli and Klebsiella spp. Jpn J Infect Dis, 62, 372-377.

9. Eng SK, Pusparajah P, Ab Mutalib NS, et al (2015): Salmonella: a review on pathogenesis, epidemiology and antibiotic resistance. Front Life Sci, 8, 284-293.

10. Erdem B, Ercis S, Hascelik G, et al (2005): Antimicrobial resistance patterns and serotype distribution among Salmonella enterica strains in Turkey, 2000-2002. Eur J Clin Microbiol Infect Dis, 24, 220-225.

11. Gantois I, Ducatelle R, Pasmans F, et al (2009): Mechanisms of egg contamination by Salmonella Enteritidis. FEMS Microbiol Lett, 33, 71

12. Gülmez D, Gür D, Hasçelik G, et al (2012): Orusal Enterik Patojenler Laboratuvar Sürveyans Ăğna (UEPLA) aahil olan bir üniversite hastanesinin deneyimleri: Dört ylllk Salmonella, Shigella ve Campylobactex venleri. Türk Mikrobiyol Cem Derg, 42, 85-92.

13. Hadimli HH, Pinarkara Y, Sakmanoğlu A, et al (2017): Serotypes of Salmonetta isolated from feces of cattle, buffalo, and camel and sensitivitiey to antibiotics in Turkey. Turk J Vet Anim Sci, 41, 193-198.

14. Hoffmann S, Scallan E (2017): Epidemiology, Cost, and Risk Analysis of Foodborne Disease. 31-63. In: Christine D, Tim A, Richard S (Eds). Foodborne Diseases. Academic Press, San Diego.

15. Kado CI, Liy ST (1981): Rapid procedure for detection and isolation of large and small plasmids. J Bacteriol, 145, 1365-1373.

16. Kaldhone P, Nayak R, Lynne AM, et al (2008): Characterization of Salmonella enterica serovar Aeidelberg from turkey-associated sources. Appl Environ Microbiol, 74, 5038-5046.

17. Karakecili F, Cikman A, Karagoz A (2017): A Salmonella typhimurium outbreak associated with food served at a wedding reception. KLIMIK Journal, 30, 131-136.

18. Kemal J (2014): A review on the public health importance of bovine salmonellosis. J Veterinar Sci Technol, 5, 1.

19. Kilic A, Bedir O, Kocak N, et al (2010): Analysis of an outbreak of Salmonella enteritidis by repetitive-sequencebased PCR and pulsed-field gel electrophoresis. Internal Medicine, 49, 31-36.

20. Klemm EJ, Shakoor S, Page AJ, et al (2018): Emergence of an extensively drug-resistant Salmonella enterica Serovar Typhi Clone Harboring a promiscuous plasmid encoding resistance to fluoroquinolones and thirdgeneration cephalosporins. MBio, 20, e00105-18.

21. Küçüker MA, Tolun V, Helmuth R, et al (2000): Phage types, antibiotic susceptibilities and plasmid profiles of SalmonellaTyphimurium and Salmonella Enteritidis strains isolated in Istanbul, Turkey. Clin Microbiol Infect, 6, 593599.

22. Kwon YK, Kim A, Kang MS, et al (2010): Prevalence and characterization of Salmonella Gallinarum in the chicken in Korea during 2000 to 2008. Poultry Sci, 89, 236-242.

23. Le Minor L (1984): Salmonella lignieres. 427-458. In: Krieg NR (Ed), Bergey's Manual of Systematic Bacteriology. Volume 1. Baltimore: Williams and Wilkins.

24. Le Minor L, Rohde R (1989): Guidelines for the preperation of Salmonella antisera. Paris: WHO Collaborating Centre for Reference and Research on Salmonella, Institut Pasteur. 
25. Nair DVT, Venkitanarayanan K, Kollanoor JA (2018): Antibiotic-resistant Salmonella in the food supply and the potential role of antibiotic alternatives for control. Foods, 7, 167.

26. Ozdemir K, Acar S (2014): Plasmid profile and pulsedfield gel electrophoresis analysis of Salmonella enterica isolates from humans in Turkey. PloS one, 9, e95976.

27. Pal M, Merera O, Abera F, et al (2015): A major foodborne disease of Global significance. Beverage Food World, 42, 21-24.

28. Pallavi S, Foley SL, Nayak R, et al (2013): Massively parallel sequencing of enriched target amplicons for highresolution genotyping of Salmonella serovars. Mol Cell Probes, 27, 80-85.

29. Pang JC, Chiu TH, Chiou CS, et al (2005): Pulsed field gel electrophoresis, plasmid profiles and phage types for the human isolates of Salmonella enterica serovar Enteritidis obtained over 13 years in Taiwan. J Appl Microbiol, 99, 1472-1483.

30. Pang JC, Chiu TH, Helmuth R, et al (2007): A pulsed field gel electrophoresis (PFGE) study that suggests a major world-wide clone of Salmonella enterica serovar Enteritidis. Int J Food Microbiol, 116, 305-312.

31. Peters TM, Berghold C, Brown D, et al (2007): Relationship of pulsed-field profiles with key phage types of Salmonella enterica serotype Enteritidis in Europe: results of an international multi-centre study. Epidemiol Infect, 135, 1274-1281.

32. Rivoal K, Protais J, Quéguiner S, et al (2009): Use of pulsed-field gel electrophoresis to characterize the heterogeneity and clonality of Salmonella serotype Enteritidis, Typhimurium and Infantis isolates abtained from whole liquid eggs. Int J Food Microbiol, 129, 180-186.

33. Sahan Ö, Aral EM, Aden MMA, et al (2016): Türkive'deki broyler tavuk işletmelerinden izole edilen Salmonella serovarlarının antimikrobiyel direnç durumu. Ankara Univ Vet Fak Derg, 63, 1-6.

34. Shah DH, Zhou X, Kim HY, et al (2012): Transposon mutagenesis of Salmonella enterica serovar Enteritidis identifies genes that contribute to nvasiveness in human and chicken cells and survival in egg albumen. Infect Immun, 80, 4203-4215.

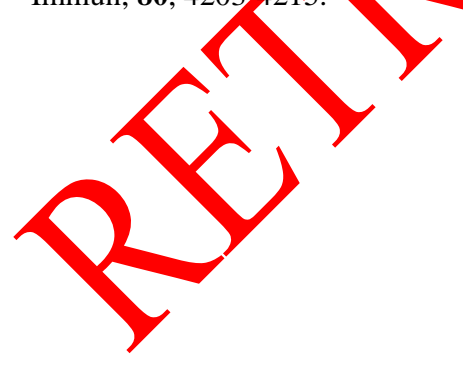

35. Stevens A, Kerouanton A, Marault M, et al (2008): Epidemiological analysis of Salmonella enterica from beef sampled in the slaughterhouse and retailers in Dakar (Senegal) using pulsed-field gel electrophoresis and antibiotic susceptibility testing. Int J Food Microbiol, 123, 191-197.

36. Sukhnanand S, Alcaine S, Warnick LD, et al (2005): DNA sequence-based subtyping and evolutionary analysis of selected Salmonella enterica serotypes. J Clin Microbiol, 43, 3688-3698.

37. Tankouo-Sandjong B, Kinde H, Wallace I (2012): Development of a sequence typing scheme for differentiation of Salmonella Enteritidis stroins. FEMS Microbiol Lett, 331, 165-175.

38. Tegegne FM (2019): Epidemiology of salmonello and its serotypes in human, food aninals, foods of animal origin, animal feed and environment. J Food Nutr Health, 2, 7-14.

39. Telli AE, Biçer Y, Kahraman HA, et al (2018): Presence and antibiotic resistonce of Salmonella spp. isolated from chicken meat and giblets consumed in Konya, Turkey. Eurasian J Vet Sdi, 34, 164-170)

40. Tenover EC, Arbeit RD, Goering RV (1997): How to select and interpret molecular strain typing methods for epidemiological studies of bacterial infections: a review for healtheare epidemiglogists. Infect Control Hosp Epidemiol, 18,426

41. Threlfal EJ, Rowe B, Ward LR (1989): Subdivision of Salmonetla enteritidis phage types by plasmid profile typing. Epidemiol Infect, 102, 459-465.

42. Tural Kara T, Özdemir H, Kurt F, et al (2015): Prevalence of Salmonella and Shigella spp. and Antibiotic Resistance Status in Acute Childhood Gastroenteritis. J Pediatr Inf, 9, 102-107.

43. Us E, Erdem B, Tekeli A, et al (2011): Salmonella serotip enteritidis izolatlarının plazmid profil analizi ve "pulsed field” jel elektroforezi ile incelenmesi. Mikrobiyol Bül, 45, 210-227.

44. Yoon KB, Song BJ, Shin MY, et al (2017): Antibiotic resistance patterns and serotypes of Salmonella spp. isolated at Jeollanam-do in Korea. Osong Public Health Res Perspect, 8, 211.

45. Zou W, Chen HC, Hise KB, et al (2013): Meta-analysis of pulsed-field gel electrophoresis fingerprints based on a constructed Salmonella database. PLoS One, 8, e59224. 